\title{
Seasonal and public holiday effects in the commercial rand/dollar exchange rate during the period 1984-1995
}

\author{
D.N. Greshnev \& E. vd M. Smit \\ Graduate School of Business, University of Stellenbosch, P.O. Box 610, Bellville, 7535 Republic of South Africa
}

\author{
Received November 1996
}

\begin{abstract}
The aim of the research is to extend the existing research into seasonalities in financial markets to the South African foreign exchange market to determine whether any of the known seasonal patterns are present in daily changes in the commercial S.A. rand/U.S. dollar exchange rate over the 11-year period, 1984 to 1995 . Only statistically significant seasonal patterns in the exchange rate changes for January versus other non-turn-of-the-month days effect are demonstrated. Contrary to the findings for the mean daily changes, the volatility of the exchange rate demonstrates persistent and statistically significant seasonal anomalies for nearly all of the examined seasonal effects. A number of popular theories offering explanation of the seasonal regularities in the financial markets are offered as possible explanations for the findings.
\end{abstract}

Die doel van die navorsing is om bestaande navorsing rakende seisoenale patrone in finansiële markte in Suid-Afrika uit te brei na die wisselkoersmark ten einde vas te stel of enige van die bekende seisoenale patrone oor die 11 -jaar-periode, 1984 tot 1985, aanwesig is in daaglikse veranderings in die kommersiële rand/dollar-wisselkoers. Die enigste statistiesbeduidende seisoenale effek wat aangetoon word, is die Januarie-versus ander nie-maandeinde-effek. In teenstelling met sodanige bevinding ten opsigte van die gemiddelde verandering, bestaan beduidende seisoenale anomalieë in die volatiliteit vir feitlik alle effekte wat ontleed is. 'n Aantal populêre teorieë word aangebied as moontlike verklaring vir die bevindings.

\section{Introduction}

Seasonality and holiday effects in financial markets have been widely examined in recent years. Empirical studies have produced convincing world-wide evidence of persistent seasonal patterns in the return-generating process in equity, bond and futures markets. These patterns are not in accordance with the Efficient Market Hypothesis (EMH). In the presence of such anomalies an investor can in theory earn abnormal riskless profits by incorporating the seasonal behaviour of security returns into his/her trading strategy.

Studies of security returns both internationally and in the South African context have revealed that returns are usually lower on Mondays and higher on Fridays (the day-of-theweek or weekend effect), high at the turn of the year (the turnof-the-year effect) and high in January (the January effect). Recently the existence of other seasonal anomalies have been documented such as a week-of-the-month, a turn-of-themonth and a month-of-the-year effect. (See the second section for a review.)

A separate body of literature is devoted exclusively to the examination of the behaviour of security returns around public holidays. It has been reported that returns for trading days immediately preceding holiday closings (pre-holiday trading days) are unusually high. Recently some researchers (see the second section) have started to investigate seasonal effects in foreign exchange markets. They found a persistent day-ofthe-week effect in daily changes and the volatility of exchange rates of all major currencies against the U.S. dollar has been detected.

The purpose of the present study is to extend previous research into seasonalities in security returns in South Africa to the South African foreign exchange market and to determine whether or not any of the known seasonal patterns are present in the daily changes of the commercial S.A. rand/U.S. dollar foreign exchange rates.

The following effects wili be investigated: day-of-the-week effect; week-of-the-month effect; month-of-the-year effect; turn-of-the-month effect; turn-of-the-year effect; January versus other non-turn-of-the-month days effect; and the holiday effect.

The article is structured as follows: the second section provides a review of the relevant literature, the third deals with the research method and the results are summarized in the fourth section. The conclusions are contained in a final section.

\section{Literature survey}

Calendar regularities in financial markets have been extensively investigated in previous empirical studies. While various hypotheses have been proposed to explain the observed seasonal anomalies there is still no general consensus on the reasons which fully account for these patterns.

A week-end (day-of-the-week) effect in share returns, that is abnormally low returns for Mondays, has been documented amongst others by Gibbons \& Hess (1981) and Keim \& Stambaugh (1984). French (1980) examines two alternative models of the process generating share returns - calendar time and trading time hypotheses. Under the calendar time hypothesis, expected returns for Mondays should be three times the expected returns for all other days of the week. Under the trading time hypothesis, returns are generated only during active trading and the expected return is the same for each day of the week. During the period studied the average return on Monday was significantly negative, which was inconsistent with both of the proposed models. Delays in the release of unfavourable corporate information until the weekend is considered a possible explanation for the weekend effect. However, in efficient markets investors should discount share prices appropriately throughout the week and weekend information should not systematically produce negative returns.

Miller (1988) explains a week-end effect in terms of peculiarities in the trading behaviour of individual investors. Individuals tend to re-evaluate their portfolios over weekends and place their orders on Mondays. Since this category of investors historically tends to be net sellers of shares, the result 
would be a little more selling than buying at the exchanges opening on Mondays which causes shares to open at prices slightly below their Friday's closings. Against this background Abraham \& Ikenberry (1994) further investigate trading patterns of individual investors and confirm that their selling activity is generally higher on Mondays than on any other weekday. They find that individuals exert substantially greater selling pressure on Mondays - with most selling occurring before 11:00 - following negative returns on Fridays. They show that when Friday's return is negative, nearly $80 \%$ of the subsequent Monday's returns are negative. However, if Friday's return is positive, more than half of the following Monday's returns are positive.

The existence of an intra-monthly pattern in the return generating process has initially been noted by stock market advisors and further explored in academic literature. Merrill for example (1966) has advised clients to make planned purchases before the start of the month and to postpone planned sales until after the middle of the month to benefit from the unusually high returns in the early days of the calendar month. Ariel (1987) also documents an intra-monthly effect in returns on stock indices over a period of 19 years. He finds that indices earn positive average returns only around the beginning and during the first half of calendar months and zero average returns during the second half.

Jordan \& Jordan (1991) examine seasonal patterns in the daily price behaviour of long-term corporate bonds. They find that although corporate bond prices display some degree of seasonal regularity, the return pattern is not the same as that documented for equities. It is observed that with the exception of the week-of-the-month effect, the results for the bond index and share index are mirror images of each other, that is effects significant for one are not significant for the other.

In South Africa Bhana (1985) examines daily returns for shares traded on the Johannesburg Stock Exchange (JSE). He finds that during the period 1978 to 1983 the average return for Monday was significantly negative while the average return for other trading days was positive with Wednesday showing the highest return. He mentions the time lag between the JSE and major overseas markets as well as the settlement procedures of the JSE as possible explanations of the Monday effect.

Hattingh \& Smit (1993) examine the seasonal patterns in the South African bond market for the Post Office, Eskom 168 and the RSA bonds and compare them with three equity indices, namely the Gold Index, Industrial Index and Overall Index. In contrast to the findings of Jordan \& Jordan (1991) they show that South African bond and share markets display similar seasonal patterns. Watson \& Smit (1994) extend the empirical research of seasonalities in the capital market to the South African share index futures market. The underlying equity indices are also examined to determine whether the seasonal patterns in futures contracts reflect the seasonal patterns in underlying equities. Similar seasonal patterns are evident in both markets although at different levels of significance.

The existence of abnormally high returns on the day preceding holidays is another puzzling anomaly reported in recent studies. Documented first by financial practitioners like Merrill (1976), the holiday effect has been extensively inves- tigated in the academic literature. Pettengill (1989) establishes a general holiday effect consisting of unusually high returns for pre-holiday trading days regardless of weekday, year or firm size. He tests two different hypotheses for possible explanation of the holiday effect namely the closed market and time diffusion hypotheses. If security returns follow a similar time-diffusion process during trading and non trading periods, reported post-holiday returns after a one-day holiday should encompass returns for a two-day period. However, he finds that post-holiday returns are inadequately explained by a time diffusion process. Tests of a closed market hypothesis show that an exchange closing unaccompanied by a traditional holiday does not produce abnormally high pre-closing returns, while unusually high returns are still documented for holidays not associated with the market closing. The study therefore also provides convincing evidence against a closed market hypothesis.

Ariel (1990) detects that the average returns on the trading day prior to holidays are nine to 14 times higher than the average returns for the remaining days of the year. Several popular theories are tested for possible explanations of the effect. He shows that since the pre-holiday variance of return is not greater but actually lower than the variance for non-holidays, the high pre-holiday return is not a reward for bearing extra risk. Bid-ask influences, January and weekend effects are found not to be responsible for the pre-holiday strength of securities. He suggests that specific investment decisions, that is preferential buying (avoidance of selling) on pre-holidays, may account for the holiday effect.

Kim \& Park (1994) provide further evidence of the holiday effect by investigating pre-holiday share price movements on three major exchanges in the U.S. and in countries with different holidays and institutional arrangements. The results show that the holiday effect exists in all three stock exchanges in the U.S. as well as in the U.K. and Japanese share markets. Furthermore, the holiday effects in U.K. and Japanese share markets are independent of the holiday effect in the U.S.

Unusually high pre-holiday returns in futures contracts are documented by Fabozzi, Ma \& Briley (1994). Testing hypotheses for explanation of the effect, they suggest that the activity of speculators that avoid taking short positions and/or are inclined to cover their short positions on the day prior to the holiday tends to drive the price of futures contracts up producing a higher pre-holiday return. They also suggest that higher trading volume around open-exchange holidays resulting in positive post-holiday return is associated with generally favourable holiday moods.

In South Africa Bhana (1994) documents a statistically significant higher mean return for the JSE Overall Actuaries Index on the trading day prior to holidays. He finds that on average the pre-holiday return is five times higher than the return for all other trading days. It is suggested that the holiday effect can be explained by simultaneous movements from bid to ask prices by market-makers on a trading day prior to a public holiday.

In contrast to security returns, seasonality in foreign exchange rate movements has not been widely investigated. Except for the day-of-the-week effect, documented in several studies (e.g. Hsieh, 1988; Baillie \& Bollerslev, 1989), exchange rate fluctuations have not been examined for any of 
the well-known seasonal anomalies associated with capital markets.

Applying a modified GARCH model to the analysis of seasonal patterns in daily exchange rate changes, Copeland \& Wang (1994) have discovered a day-of-the-week effect in exchange rate movements. Their study shows consistent increases in foreign exchange rates (measured in foreign currency per U.S. dollar) on Mondays and a relatively significant decrease on Thursdays. A statistically significant day-ofthe-week effect is reported for the volatility in the foreign exchange markets. Empirical findings indicate that the most volatile periods are Thursdays (the day when the U.S. money supply figures are announced), followed by Mondays. Wednesdays are found to be the least volatile characterized by a reduced amount of trading prior to the announcement of important macro-economic news.

\section{Research method}

The seasonal behaviour of the commercial Rand/Dollar foreign exchange rate is investigated over an 11-year sample period over which the changes in the Rand/Dollar exchange rates were determined to a large extent by the market forces of demand and supply, that is the period May 1984 to February 1995.

The daily changes in the foreign exchange rate are computed as:

$\Delta S_{1}=\left(S_{1}-S_{1-1}\right) / S_{1-1}$

where:

$\Delta S_{1}=$ daily change in the $R / \$$ exchange rate at the end of day $\mathrm{t}$;

$S_{t}=$ spot exchange rate of the commercial rand per U.S. dollar at the end of day $t$;

$S_{1-1}=$ spot exchange rate of the commercial rand per U.S. dollar at the end of day $t-1$.

The daily rates were obtained from the Sanlam database and were cross-checked and augmented with corresponding rates from the I-Net data base. If the rand appreciates during a trading day - the $R / \$$ exchange rate decreases - the reported daily change in the exchange rate is negative. If the rand depreciates - the spot rate increase - the reported daily change is positive.

To investigate seasonal effects, daily rate changes are grouped according to each of the seasonal patterns under review, similar to the method used by Jordan \& Jordan (1991) and Watson \& Smit (1994). To establish whether a day-of-theweek effect exists, the daily exchange rate changes are classified according to the day of the week. The null hypothesis is that average daily changes in the exchange rate are equal across the different trading days of the week. To investigate a week-of-the-month effect, the daily rate changes are grouped into four different categories according to the week of the month. The first trading week of a month consisting of the first five trading days of a month is classified as week 1 , the second trading week of a month consisting of the following five trading days is classified as week 2 , the third trading week of a month is defined as week 3 and the last trading week - classified as week 4 - will accommodate the remaining trading days at the end of a month. In months with more than 20 trading days, week 4 will consist of more than five trading days, while in months with less than 20 trading days week 4 will consist of less than five trading days. The null hypothesis is that the mean daily changes of the exchange rate are equal across different trading weeks of a month.

To examine a month-of-the-year effect in daily exchange rate changes, observations are classified according to the month of the year. The null hypothesis that the mean daily changes of the exchange rate are equal across different months of the year is then tested. To establish whether a turnof-the-month effect exists, the exchange rate changes are classified into two groups; turn-of-the-month days and non-turnof-the-month days. The turn-of-the-month days consist of the first four trading days of each month plus the last trading day of the previous month. The null hypothesis that the mean daily change of the exchange rate for turn-of-the-month days is equal to that of the non-turn-of-the-month days is investigated.

To examine a turn-of-the-year effect daily changes are classified into two groups; the turn-of-the-year days and other turn-of-the-month days. The turn-of-the-year days are defined as the last trading day in December plus the first four trading days in January. The null hypothesis that the mean exchange rate change for turn-of-the-year days is equal to mean changes for other turn-of-the-month days is tested. To establish whether there is abnormally high appreciation of the rand in January beyond the turn-of-the-year days - so-called January versus other non-turn-of-the-month days effect - the turnof-the-month days are deleted in each month. Non-turn-ofthe-month observations are then classified into two groups, namely January non-turn-of-the-month days and other nonturn-of-the-month days. The null hypothesis that the mean daily foreign exchange change for January non-turn-of-themonth days is equal to that of other non-turn-of-the-month days is examined.

To investigate whether the rand shows abnormal strength or weakness on a trading day prior to public holidays (holiday effect), the daily exchange rate changes are divided into three subgroups; changes for pre-holidays, post-holidays and nonholidays. The null hypothesis is that the mean daily foreign exchange rate changes are equal across the days prior to public holidays, the days following holidays and non-holidays. Over the sample period there were eleven public holidays in the calendar year namely New Year's Day, Good Friday, Easter Monday (Family Day), Founder's Day, Workers' Day, Ascension Day, Republic Day, Kruger Day, Day of the Vow, Christmas Day and Day of Goodwill. Some of these holidays (for example Good Friday and Easter Monday) invariably fall on a weekday and therefore are always accompanied by an extra market closing. Other holidays (for example Christmas Day and Day of the Vow) may fall on weekends and therefore will not always provide for a separate market closing. In addition, Ascension Day is never accompanied by a foreign exchange market closing. The Workers' Day provides an extra forex market closing starting from 1987. No distinction is made in this study between holidays accompanied by market closings and those which are not. Although there are eleven public holidays in a calendar year, there are only nine pre-holiday periods because Good Friday and Easter Monday, as 
well as Christmas Day and Day of goodwill, fall on consecutive trading days and have a common market closing.

Roll (Ariel, 1990) observes that the period of January high returns starts on the last trading day of December. Since this day is a trading day prior to the New Year, it is also included in the pre-holidays exchange rate data set. To investigate whether a January effect is partially responsible for the holiday effect through its impact on the pre-New Years Day, all turn-of-the-year days are deleted and the above-stated hypothesis is then tested again.

To test for linkages between S.A. and U.S. forex markets, the public holidays common to both countries (New Years Day, Good Friday, Workers' Day, Day of Goodwill and Christmas Day) are omitted from the data. In their absence, daily foreign exchange rate changes are examined for the following original South African holidays: Founder's Day (6 April), Republic Day (31 May), Kruger Day (10 October) and Day of the Vow (16 December). The study then tests the null hypothesis that foreign exchange rate changes are equal across South African pre-holidays, post-holidays and nonholidays.

A set of summary statistics has been prepared for each set of data and each seasonal pattern investigated and these are available from the authors. These sets include coefficients of skewness, kurtosis and the variance of exchange rate changes. Seasonal patterns in the volatility of the foreign exchange market, described by the variance of daily exchange rate changes, are also investigated. For each seasonal effect two tests for homogeneity of variances - Cochran's and Bartlett's tests -are conducted. The objectives are, firstly, to determine the statistical significance of seasonal effects in volatility of the forex market and, secondly, to produce evidence for/ against the validity of the ANOVA F-test. To examine whether the seasonal effects persisted during the entire sample period, the eleven years of foreign-exchange-rate-data are divided into two five-and-a-half-year sub-periods. Seasonality in the exchange rate changes is then separately investigated within each of the sub-periods.

Political unrest, the 1985 foreign debt crisis and the subsequent re-introduction of the financial rand caused considerable daily fluctuations of the commercial exchange rate, especially during the period 27.08 .85 to 4.09 .85 . To determine whether this highly volatile period is partially responsible for any of the seasonalities in the exchange rate changes, seasonal effects are also examined in the absence of the most extreme observations. The following four trading days are omitted from the data for additional tests: 27 August 1985 (Tuesday) - Rand depreciates by $11.428 \%, 02$ September 1985 (Monday) - Rand appreciates by $22.514 \%, 03$ September 1985 (Tuesday) - Rand depreciates by $9.058 \%, 04$ September 1985 (Wednesday) - Rand depreciates by $6.066 \%$.

One-way analysis of variance (ANOVA) F-tests are used to analyse the data. However, values of the standardized coefficients of skewness and kurtosis indicate considerable deviations from a normal distribution in all of the analyses performed. Furthermore, based on the results of Cochran's and Bartlett's tests for the homogeneity of variances, the hypothesis that variances are equal across corresponding sets of data is rejected in nearly all cases. Therefore the results of the F-tests are under suspicion and the non-parametric Kruskal-
Wallis test is used to augment the ANOVA. In both the ANOVA F-test and the Kruskal-Wallis test the 5\% significance level is used to determine whether the observed seasonal pattern is statistically significant.

\section{Results}

\section{Day-of-the-week effect}

The day-of-the-week effect tests results are summarized in Table 1. The highest mean changes over the entire sample period and Period 2 occurs on Wednesdays, while the lowest mean changes in the exchange rate is observed on Thursdays. Interestingly, the Wednesday pattern has also been established for all major currencies against the U.S. dollar by Baillie \& Bollerslev (1989) and Copeland \& Wang (1994). Although not the highest, Wednesday mean exchange rate changes remains second largest throughout Period 1 and during the entire period with the omitted extreme observations.

The fact that the smallest change in the exchange rate occurs on Thursday corresponds to the empirical findings of Copeland \& Wang (1994). The Thursday effect persists only in the first five years of the sample data, disappearing during the second sub-period. The fact that the exchange rate data without outliers display neither a Wednesday nor a Thursday effect indicates that the highly volatile time in August/September 1985 partially accounts for the observed anomalies. In the absence of outliers, the mean daily change is the highest on Mondays and the smallest on Tuesdays. Interestingly, the second highest mean daily change nevertheless occurs on Wednesday and the second lowest on Thursday, duplicating the day-of-the-week effects in international foreign exchange markets.

Seasonal patterns in the information flow may serve as a possible explanation of the Monday and Tuesday patterns in the exchange rate data with omitted outliers. The fact that negative news affecting the foreign exchange rate is usually announced over weekends causes an abnormal decrease in the value of the rand on the Monday following the announcement. On Tuesdays, when the initial shock is absorbed and the panic buying of dollars decreases, the rand re-captures some of its value lost on the previous trading day. It results in

Table 1 Day-of-the-week effect test results

\begin{tabular}{|c|c|c|c|c|}
\hline & $\begin{array}{c}\text { Entire } \\
\text { period } \\
\text { 1984-1995 }\end{array}$ & $\begin{array}{l}\text { Period 1: } \\
\text { 1984-1989 }\end{array}$ & $\begin{array}{l}\text { Period 2: } \\
\text { 1990-1995 }\end{array}$ & $\begin{array}{c}\text { Entire period } \\
\text { without } \\
\text { extremes }\end{array}$ \\
\hline \multicolumn{5}{|c|}{ Mean daily changes: } \\
\hline high & Wednesday & Tuesday & Wednesday & Monday \\
\hline low & Thursday & Thursday & Tuesday & Tuesday \\
\hline \multicolumn{5}{|l|}{ P-value: } \\
\hline ANOVA F-test & 0.9650 & 0.7332 & 0.0191 & 0.8571 \\
\hline KW-test & 0.2411 & 0.8817 & 0.0000 & 0.1905 \\
\hline \multicolumn{5}{|c|}{ Variance of changes: } \\
\hline high & Monday & Monday & Monday & Monday \\
\hline low & Thursday & Thursday & Thursday & Thursday \\
\hline \multicolumn{5}{|l|}{ P-value: } \\
\hline Cochran's C test & 0.0000 & 0.0000 & 0.0031 & 0.0249 \\
\hline Bartlett's test & 0.0000 & 0.0000 & 0.0055 & 0.0000 \\
\hline
\end{tabular}


a negative (during Period 2) or at least in a much lower mean daily change on Tuesdays. It is interesting to note that the day-of-the-week effect documented for the Period 2 Wednesday/Tuesday seasonal anomalies - is statistically significant. However, similar to both of the previously mentioned studies, none of the results for other sets of data is statistically significant at the $5 \%$ level of significance.

Contrary to the mean daily changes, the day-of-the-week pattern in the volatility in the South African foreign exchange market measured by the variance of daily changes is clear and statistically significant at the $5 \%$ level throughout the sample period. The test results indicate that the most volatile times occur on Mondays while Thursdays seem to be the least volatile. The practice of announcing important news over the weekend appears to be consistent with the finding that Mondays are the most volatile days in a week. The observed seasonal pattern of the volatility is documented for both fiveyear sub-periods as well as for the entire period with omitted extreme observations. The results obtained for the volatility of the $R / \$$ daily exchange rate in this study are similar to those of Baillie \& Bollerslev (1989) in that Monday's variance for the international currency markets is also the highest in a week. However, they differ significantly from the findings of Copeland \& Wang (1994) who suggest that the most volatile time in major currencies against the U.S. dollar is on Thursdays. On the contrary, the South African forex market over this period is found to be least volatile on Thursdays.

\section{Week-of-the-month effect}

The week-of-the-month tests results are summarized in Table 2. Week-of-the-month seasonal patterns in the foreign exchange rate data are practically non-existent. For both the entire period and the first five-year period the highest mean exchange rate change occurs during the last trading week of the month. Results for the second five-year period and the entire period without outliers show a totally different seasonal pattern, characterized by the highest mean daily change in the third trading week (in the absence of outliers week 3 is the second highest) and the lowest in week 4. Extreme fluctuations of the exchange rate during the four trading days in August/September 1985 seem to be responsible for the overall seasonal pattern observed during the entire sample period. In their absence the overall sample period produces a similar seasonal pattern to that of the second five-year period. However, none of the test results for the mean daily change is statistically significant at the $5 \%$ level of significance.

The test results show a significant week-of-the-month effect in the variance of the daily foreign exchange rate changes. The first five trading days of a calendar month are the most volatile for both the entire period and the first fiveyear period. The second trading week of the month is found to be the least volatile for the same sets of data. The observed pattern of volatility in the foreign exchange rate during the entire sample also seems to be caused largely by the fluctuations of the exchange rate during August/September 1985. Although during both Period 2 and the entire period without extremes the variances of the exchange rate changes show different seasonal patterns, for neither of the two periods the patterns are statistically significant.
Table 2 Week-of-the-month effect test results

\begin{tabular}{lcccc}
\hline & $\begin{array}{c}\text { Entire } \\
\text { period } \\
1984-1995\end{array}$ & $\begin{array}{c}\text { Period 1: } \\
1984-1989\end{array}$ & $\begin{array}{c}\text { Period 2: } \\
1990-1995\end{array}$ & $\begin{array}{c}\text { Entire period } \\
\text { without } \\
\text { extremes }\end{array}$ \\
\hline $\begin{array}{l}\text { Mean daily changes: } \\
\text { high }\end{array}$ & week 4 & week 4 & week 3 & week 2(3) \\
low & week 1 & week I & week 4 & week 4 \\
$\begin{array}{l}\text { P-value: } \\
\text { ANOVA F-test }\end{array}$ & 0.9878 & 0.9724 & 0.7171 & 0.9883 \\
KW-test & 0.9333 & 0.7101 & 0.7523 & 0.9398 \\
$\begin{array}{l}\text { Variance of changes: } \\
\text { high }\end{array}$ & week 1 & week 1 & week 3 & week 4 \\
low & week 2 & week 2 & week 4 & week 1 \\
$\begin{array}{l}\text { P-value: } \\
\text { Cochran's C test }\end{array}$ & 0.0000 & 0.0000 & 0.6183 & 0.0760 \\
Bartlett's test & 0.0000 & 0.0000 & 0.2672 & 0.0076 \\
\hline
\end{tabular}

\section{Month-of-the-year effect}

The month-of-the-year effect tests results are summarized in Table 3. The highest mean positive daily change in the exchange rate over the entire sample period, irrespective of extreme observations, occurs in May. The relative degree of depreciation in May is also the second highest during the first five-year period.

Negative changes in mean daily exchange rates (rand appreciation) for the entire period are detected for January, September and November, with September's change being largest, although for the sample data without outliers, the peak in seasonal strength of the rand occurs in November. This seasonal pattern in the appreciation of the rand is persistent throughout the first five-year period only - with the highest mean appreciation in January. Period 2 shows a totally different month-of-the-year pattern: the only documented negative mean changes occur in July and August, the latter being the larger. However, none of the results obtained for the month-of-the-year effect is statistically significant at the $5 \%$ level of significance.

In contrast, the variance in the foreign exchange rate changes displays a significant month-of-the-year effect. During both the entire sample period and the first five-year subperiod the market was the most volatile in September. December's variance of exchange rate changes was persistently the lowest for all groups of data except Period 2. According to the test results the seasonal pattern in the volatility changed in the second five-year sub-period with April's variance being highest with a low in November. The evidence indicates that the abnormal exchange rate fluctuations in September 1985 are responsible for the observed seasonal pattern of the volatility in the forex market over the entire period, with September's variance being highest. For the sample data with omitted extreme observations the variance is found to be highest in August and lowest in December. Reduced volume of foreign exchange transactions reflecting a generally decreasing level of economic activity in the country towards the end of the year and before the Christmas holiday period may account for the lower volatility in December. 
Table 3 Month-of-the-year effect test results

\begin{tabular}{lcccc}
\hline & $\begin{array}{c}\text { Entire } \\
\text { period } \\
1984-1995\end{array}$ & $\begin{array}{c}\text { Period 1: } \\
1984-1989\end{array}$ & $\begin{array}{c}\text { Period 2: } \\
1990-1995\end{array}$ & $\begin{array}{c}\text { Entire period } \\
\text { without } \\
\text { extremes }\end{array}$ \\
\hline $\begin{array}{l}\text { Mean daily changes: } \\
\text { high }\end{array}$ & May & July & March & May \\
low & September & January & August & November \\
$\begin{array}{l}\text { P-value: } \\
\text { ANOVA F-test }\end{array}$ & 0.3907 & 0.3035 & 0.3979 & 0.2521 \\
KW-test & 0.1407 & 0.1690 & 0.3250 & 0.1302 \\
Variance of changes: & & & & \\
high & September & September & April & August \\
low & December & December & November & December \\
P-value: & & & & \\
Cochran's C test & 0.0000 & 0.0000 & 0.0000 & 0.0000 \\
Bartlett's test & 0.0000 & 0.0000 & 0.0000 & 0.0000 \\
\hline
\end{tabular}

\section{Turn-of-the-month effect}

The turn-of-the-month effect tests results are summarized in Table 4. Over the sample period daily foreign exchange rate changes display a non-significant turn-of-the-month effect similar to that documented for the equity and bond markets. The highest mean daily change occurs on turn-of-the-month (TOM) days, while non-turn-of-the-month (NTOM) days show a distinguishably lower mean change. The results indicate that during the first four trading days of a month and the last day of the previous month the rand depreciates on average twice as much as during the rest of the days. Since both the entire-period-data and entire-period-data-withoutextremes display similar turn-of-the-month effects, the omitted observations (the period 27.08.1985 to 04.09.1985) are not solely responsible for the detected anomaly. This turnof-the-month seasonal pattern persists during the first five years of the sample data and completely reverses itself during the second sub-period. However, none of the turn-of-themonth test results are statistically significant.

Table 4 Turn-of-the-month effect test results

\begin{tabular}{lcccc}
\hline & $\begin{array}{c}\text { Entire } \\
\text { period } \\
1984-1995\end{array}$ & $\begin{array}{c}\text { Period 1: } \\
1984-1989\end{array}$ & $\begin{array}{c}\text { Period 2: } \\
1990-1995\end{array}$ & $\begin{array}{c}\text { Entire period } \\
\text { without } \\
\text { extremes }\end{array}$ \\
\hline $\begin{array}{l}\text { Mean daily changes: } \\
\text { high }\end{array}$ & $\begin{array}{c}\text { TOM* } \\
\text { low }\end{array}$ & TOM & NTOM & TOM \\
P-value: & NOM* & NTOM & TOM & NTOM \\
ANOVA F-test & 0.4749 & 0.3638 & 0.5024 & 0.4924 \\
KW-test & 0.2355 & 0.0418 & 0.2485 & 0.2839 \\
Variance of changes: & & & & \\
high & TOM & TOM & TOM & TOM \\
low & NTOM & NTOM & NTOM & NTOM \\
P-value: & & & & \\
Cochran's C test & 0.0000 & 0.0000 & 0.2282 & 0.0000 \\
Bartlett's test & 0.0000 & 0.0000 & 0.3007 & 0.0004 \\
\hline *TOM: turn-of-the-month days: NTOM: non-turn-of-the-month days \\
\hline
\end{tabular}

The volatility of the foreign exchange rate shows a persistent turn-of-the-month seasonal pattern. Throughout all periods the variance of changes was highest during the turnof-the-month trading days and the lowest during the rest of the month. This observed seasonal pattern in the volatility of the exchange rate corresponds with the seasonal effects documented for security returns. With the exception of Period 2, the turn-of-the-month effect in the volatility of the exchange rate is statistically significant at the $5 \%$ level of significance for all other data groupings.

\section{Turn-of-the-year effect}

These tests results are summarized in Table 5. The daily foreign-exchange-rate-data over the entire sample period display a hardly distinguishable and non-significant turn-ofthe-year effect. The mean daily change on TOY days is only marginally higher than that on other turn-of-the-month (TOM) days of the year. The almost four times higher mean change on TOY days $(0.0038)$ than on TOM days $(0.00011)$ over the last five years of the sample period accounts for the seeming presence of the TOY effect. The test results for the turn-of-the-year effect in the daily spot R/ $\$$ foreign exchange rate changes are not significant at the $5 \%$ level of significance for all data groupings.

However, volatility of the foreign exchange market shows a statistically significant turn-of-the-year effect for all groups of data except the Bartlett's test in Period 2. The most volatile times in the forex market persistently occur during turn-ofthe-month days while the turn-of-the-year days display a significantly lower volatility. The fact that the last trading day of the year and the first four trading days of the following year are less volatile than the rest of the turn-of-the-month days is consistent with the previously documented month-of-the-year effect in the foreign exchange rate volatility. According to the test results the volatility of the forex market in December continues to be abnormally low throughout the turn-of-the year days. The generally low level of economic activity in the country during the Christmas period seems to be responsible

Table 5 Turn-of-the-year effect test results

\begin{tabular}{|c|c|c|c|c|}
\hline & $\begin{array}{c}\text { Entire } \\
\text { period } \\
1984-1995 \\
\end{array}$ & $\begin{array}{c}\text { Period 1: } \\
\text { 1984-1989 }\end{array}$ & $\begin{array}{c}\text { Period 2: } \\
1990-1995\end{array}$ & $\begin{array}{c}\text { Entire period } \\
\text { without } \\
\text { extremes }\end{array}$ \\
\hline \multicolumn{5}{|c|}{ Mean daily changes: } \\
\hline high & TOY* & TOM & TOY & TOY \\
\hline low & TOM* & TOY & TOM & TOM \\
\hline \multicolumn{5}{|l|}{ P-value: } \\
\hline ANOVA F-test & 0.9950 & 0.9686 & 0.7266 & 0.9950 \\
\hline KW-test & 0.2643 & 0.4251 & 0.5747 & 0.2643 \\
\hline \multicolumn{5}{|c|}{ Variance of changes: } \\
\hline high & TOM & TOM & TOY & TOM \\
\hline low & TOY & TOY & TOM & TOY \\
\hline \multicolumn{5}{|l|}{ P-value: } \\
\hline Cochran's C test & 0.0000 & 0.0000 & 0.0041 & 0.0000 \\
\hline Bartlett's test & 0.0000 & 0.0002 & 0.0784 & 0.0000 \\
\hline
\end{tabular}


for the observed turn-of-the-year effect in the foreign exchange market volatility.

\section{January versus other non-turn-of-the-month days effect}

The January versus other non-turn-of-the-month days effect tests results are summarized in Table 6. The daily foreign exchange rate changes display a significant January effect throughout the entire sample period, irrespective of omitted observations. The rand is consistently stronger in January than during other non-turn-of-the-month days. With the exception of Period 2, all sets of foreign-exchange-rate-data show a significantly negative mean change in January. Although during Period 2 the mean daily change is positive, it is still much smaller than that during the rest of non-turn-of-themonth days. It is interesting that the foreign exchange rate changes display a January non-turn-of-the-month effect similar to that of the S.A. futures, bond and equity markets. Hattingh \& Smit (1993) and Watson \& Smit (1994) found that the Gold Index, the Industrial Index and the Overall Index of the JSE persistently show lower (in most cases, negative) returns in January during non-turn-of-the-month days when compared to other non-turn-of-the-month days.

The correlation between the two financial markets may not be incidental. With the stronger rand in January the revenues from the sales of gold, other minerals as well as from the export of consumer goods are bound to be lower when denominated in rand. Since the share price reflects the expected share returns in the future, the JSE indices, especially the Gold Index, tends to fall and display negative seasonal changes in January. In non-efficient markets this information is unlikely to be discounted throughout the year and therefore may cause a persistent seasonal effect.

For the entire period, Period 2 and the entire period with omitted extremes, the results of the January versus other nonturn-of-the-month days effect tests are statistically significant at the $5 \%$ level of significance. However, the January effect during Period 1 is only significant at the $5.51 \%$ significance level. The hypothesis that the mean daily changes in the exchange rate are equal between the two sets of data can be rejected for most of the sample periods.

The variance of the foreign exchange rate changes shows a distinctive although non-significant January versus other nonturn-of-the-month days. The volatility of the S.A. forex market in January is usually higher than during other non-turn-ofthe-month days in the year. This observed anomaly may be consistent with the hypothesis that the seasonality in the arrival of important economic information into the market is at least partially responsible for the seasonal effects in the volatility of the foreign exchange rate. Hypothesized delays with the release of information till the beginning of a new year persistently increase the volatility of the foreign exchange market in January. This is consistent with the findings of Copeland \& Wang (1994: 522) who show that the foreign exchange markets are most volatile immediately after the announcement of important news. As previously shown, such seasonal patterns in the information flow have an opposite effect on the volatility of the forex market in December and during the January turn-of-the-year days. However, none of the variance test results (except Cochran's C test for Period 2) is statistically significant at the $5 \%$ level of significance.
Table 6 January versus other non-turn-of-the-month days effect test results

\begin{tabular}{lcccc}
\hline & $\begin{array}{c}\text { Entire } \\
\text { period } \\
1984-1995\end{array}$ & $\begin{array}{c}\text { Period 1: } \\
1984-1989\end{array}$ & $\begin{array}{c}\text { Period 2: } \\
1990-1995\end{array}$ & $\begin{array}{c}\text { Entire period } \\
\text { without } \\
\text { extremes }\end{array}$ \\
\hline $\begin{array}{l}\text { Mean daily changes: } \\
\text { high }\end{array}$ & $\begin{array}{r}\text { NTOM* } \\
\text { low }\end{array}$ & NTOM & NTOM & NTOM \\
$\begin{array}{l}\text { P-value: } \\
\text { ANOVA F-test }\end{array}$ & January & January & January \\
KW-test & 0.0481 & 0.0551 & 0.4315 & 0.0481 \\
Variance of changes: & 0.0208 & 0.0254 & 0.2577 & 0.0208 \\
high & & & & \\
low & January & January & January & January \\
P-value: & NTOM & NTOM & NTOM & NTOM \\
Cochran's C test & 0.1016 & 0.0061 & 0.3730 & 0.1016 \\
Bartlett's test & 0.3506 & 0.1356 & 0.5917 & 0.3506 \\
\hline *NTOM: non-turn-of-the-month days & & \\
\hline
\end{tabular}

\section{Holiday effects}

The results of the holiday effect tests are summarized in Table 7. Daily changes in the foreign exchange rate show a distinctive pattern in that the mean daily changes are persistently negative on pre-holidays and marginally different from all other days of the year on a trading day following a holiday. Disproportionate seasonal appreciation of the rand on a trading day prior to a public holiday persists throughout the entire sample.

This pattern differs from the one documented for both international and South African capital markets in that the security returns are significantly higher on pre-holidays compared to non-holiday returns. In the South African forex market the pre-holiday pattern of exchange rate movements is totally reversed.

One of the popular theories which is consistent with the test results ascribes the appreciation of the rand on pre-holidays to a particular trading behaviour of the forex market participants. The banks and other foreign exchange dealers may be reluctant to take short positions in rands on a trading day immediately prior to a public holiday. Therefore, the demand for rands tends to exceed the supply and the price of local currency measured in U.S. dollars consequently rises.

To examine whether the observed pre-holiday appreciation is a manifestation of the January effect, trading days before and after the New Years Days were excluded from the sample. The test results show that in the absence of these days there is still a distinctive holiday effect present. On the trading day prior to a public holiday the rand appreciates on average by $0.000479 \%$, subsequently depreciating by $0.000469 \%$ on a post-holiday trading day. However, none of the test results are significant at the $5 \%$ level of significance.

To examine the international linkages in the holiday effect across different foreign exchange markets, the public holidays common to the South African and the U.S. forex markets were excluded from analysis. According to the test results, the $R / \$$ exchange rate changes show a persistent holiday effect even in the absence of the U.S. linkage. The rand 
appreciates on average by $0.0004 \%$ on a trading day prior to a South African public holiday and depreciates by $0.0019 \%$ on a post-holiday trading day. None of the holiday effects are, however, statistically significant at the $5 \%$ level of significance. In short, the daily foreign-exchange-rate-data displays a pattern around holidays but none of the ANOVA F-test and the non-parametrical Kruskal-Wallis test results are statistically significant at the $5 \%$ level of significance.

The variance of the foreign exchange rate changes shows a strong holiday effect for all groups of data. The volatility is persistently at its lowest on a trading day prior to a public holiday. Non-holidays (post-holidays for Period 2) display higher level of volatilities than pre-holidays.

Fabozzi, Ma \& Briley (1994) find evidence that traders in the futures markets appear to avoid trading in the periods immediately before holiday closings. If the trading behaviour of S.A. forex market participants is similar to that of futures dealers, the decreased volatility may be ascribed to the reduced trading activity in the foreign exchange market prior to public holidays.

The fact that post-holidays display a lower degree of volatility than non-holidays (with the exception of Period 2) corresponds with the findings of Copeland \& Wang (1994) who established that unlike Mondays, the foreign exchange markets are relatively quiet upon reopening immediately after a holiday.

Furthermore, the results of the tests show that the significantly low volatility of the forex market on a trading day prior to a public holiday is not caused by the January effect. Nonholidays are found to be the most volatile in the absence of the New Years Day observations. Controlled for international linkages, the S.A. forex market displays a different pattern in volatility around the country's original public holidays. Contrary to the above-stated findings, the volatility on post-holiday trading days is found to be lowest. The highest volatility around uniquely South Africa's holidays still occurs on nonholidays.

Table 7 Holiday effect test results

\begin{tabular}{lccccc}
\hline & $\begin{array}{c}\text { Entire } \\
\text { period } \\
1984-1995\end{array}$ & $\begin{array}{c}\text { Period I: } \\
1984- \\
1989\end{array}$ & $\begin{array}{c}\text { Period 2: } \\
1990- \\
1995\end{array}$ & $\begin{array}{c}\text { TOY } \\
\text { days } \\
\text { omitted }\end{array}$ & $\begin{array}{c}\text { S.A. } \\
\text { holiday } \\
\text { only }\end{array}$ \\
\hline $\begin{array}{l}\text { Mean daily changes: } \\
\text { high }\end{array}$ & Non-H* & Non-H & Non-H & Non-H & Post-H \\
low & Pre-H* & Pre-H & Pre-H & Pre-H & Pre-H \\
$\begin{array}{l}\text { P-value: } \\
\text { ANOVA F-test }\end{array}$ & 0.7871 & 0.9390 & 0.4205 & 0.8771 & 0.7325 \\
KW-test & 0.6515 & 0.9208 & 0.5596 & 0.8223 & 0.4702 \\
Variance of changes: & & & & & \\
high & Non-H & Non-H & Post-H* & Non-H & Non-H \\
low & Pre-H & Pre-H & Pre-H & Pre-H & Post-H \\
P-value: & & & & & \\
Cochran's C test & 0.0000 & 0.0000 & 0.0000 & 0.0000 & 0.0000 \\
Bartlett's test & 0.0000 & 0.0000 & 0.2469 & 0.0000 & 0.0000 \\
\hline
\end{tabular}

*Non-H: non-holidays; Pre-H: pre-holidays, Post-H: post-holidays
In contrast to the mean daily changes, the volatility of the South African foreign exchange market displays a statistically significant holiday effect (with an exception of Period 2) at the $5 \%$ level of significance for all groups of data.

\section{Conclusions}

The research provide new insights into the seasonal behaviour of the South African exchange rate and its volatility. The article extends the empirical research of seasonalities in the S.A. financial markets to the country's foreign exchange market. Using established techniques, a range of well-known seasonal effects are examined over the period 1984 to 1995.

The empirical findings show that some of the known seasonal effects in security returns also exist in the South African foreign exchange market. Daily foreign exchange rate changes display a statistically significant January versus other non-turn-of-the-month days effect for all groups of data except for the January effect during Period 1 which is significant only at the $5.51 \%$ significance level. The abnormal appreciation of the rand in January is the only significant seasonal effect in the S.A. foreign exchange market that is fairly consistently observed throughout all sample periods.

The day-of-the-week effect in the daily exchange rate changes is statistically significant only over the last five years of the sample. During this period the rand persistently depreciates on Wednesdays and shows abnormal strength on Tuesdays. Although the day-of-the-week effect is visible for all data sets, none of the other results is significant. These results correspond with the international findings of Baillie \& Bollerslev (1989) and Copeland \& Wang (1994) in that all major world currencies display similar effects against the U.S. dollar on Wednesdays. The fact that the lowest mean change in the $R / \$$ exchange rate occurs on Thursday (for the entire sample period only) also corresponds with the empirical findings of Copeland \& Wang (1994).

The daily exchange rate changes show indications of month-of-the-year, turn-of-the-month and holiday patterns. However, none of these seasonal patterns are statistically significant. The week-of-the-month and the turn-of-the-year effects are practically unobservable.

The results indicate that in the absence of January effect there is still a pre-holiday anomaly. The study has also produced empirical evidence that the international linkage is not responsible for the observed pre-holiday appreciation of the rand against the U.S. dollar.

Persistent appreciation of the rand during January non-turnof-the-month days and on a trading day prior to public holidays shows some inefficiencies of the S.A. foreign exchange market. An active forex trader may capitalize on the detected seasonalities by adhering to a simple trading strategy: buy U.S. dollars/sell S.A. rands in January and immediately before public holidays while holding back or taking the opposite position in these currencies during other periods. Even if transaction costs tend to neutralize the expected benefits of such trading rule, some additional income can be derived by delaying the planned purchases/sales of currencies till seasonally favourable periods.

Contrary to the mean daily changes, the volatility of the forex market displays clear and statistically significant seasonal patterns for nearly all sets of data. The variance of the daily 
exchange rate changes display a day-of-the-week, a monthof-the-year, a week-of-the-month, a turn-of-the-month, a turn-of-the-year and a holiday effect. The January versus other non-turn-of-the-month days effect, while being the only statistically significant seasonal effect for the mean daily changes in the exchange rate, has not been detected for the variance of these changes. The test results indicate that the most volatile times in the South African currency market $\alpha$ cur on Mondays, in August/September, at the turn of the month and during the first trading week of the month. On the other hand, the forex market is usually the least volatile on Thursdays, in December and during the turn-of-the-year days as well as on a trading day immediately prior to a public holiday.

The seasonal effects observed in the variance of the daily exchange rate changes will have important consequences for the pricing of foreign exchange options, the specification of risk-return relationships and the use of dummy variables when testing for conditional heteroscedasticity in exchange rate movements.

\section{References}

Abraham, A. \& Ikenberry, D.I. 1994. The individual investor and the weekend effect, Journal of Financial and Quantitative Analysis, 29(2): 263-277.

Ariel, R.A. 1987. A monthly effect in stock returns, Journal of Financial Economics, 18: 161-174.

Ariel, R.A. 1990. High stock returns before holidays: existence and evidence on possible causes, Journal of Finance, 45(5): 16111626.

Baillie, R. \& Bollerslev, T. 1989. The message in daily exchange rates: a conditional-variance tale, Journal of Business and Economic Statistics, 7(3): 297-305.

Bhana, N. 1985. The Monday effect on the Johannesburg Stock Exchange, South African Journal of Business Management, 16(1):711 .
Bhana, N. 1994. Public holiday share price behaviour on the Johannesburg Stock Exchange, Investment Analysts Journal, 39: 45-49.

Copeland, L. \& Wang, P. 1994. Estimating daily seasonality in foreign exchange rate changes, Journal of Forecasting, 13: 519-528.

Fabozzi, F., Ma, C. \& Briley, J. 1994. Holiday trading in futures markets, Journal of Finance, 49(1): 307-322.

French, K.R. 1980. Stock returns and the weekend effect, Journal of Financial Economics, 8: 55-69.

Gibbons, M.R. \&Hess, P. 1981. Day of the week and asset returns, Journal of Business, 54: 579ёP596.

Hattingh, F.S. \& Smit, E.v.d.M. 1993. Seisoenale patrone in the Suid-Afrikaanse kapitaalmark, South African Journal of Business Management, 24(4): 142-146.

Hsieh, D. 1988. The statistical properties of daily foreign exchange rates: 1974-1983, Journal of International Economics, 24: 129145.

Jordan, S.D. \& Jordan, B.D. 1991. Seasonality in daily bond returns, Journal of Financial and Quantitative Analysis, 26(2): 269-285.

Keim, D. \& Stambaugh, R. 1984. A further investigation of the weekend effect in stock returns, Journal of Finance, 39: 813-834.

Kim, S. 1988. Capitalizing on the weekend effect, Journal of Portfolio Management, 14: 59-63.

Kim, C. \& Park, J. 1994. Holiday effects and stock returns: further evidence, Journal of Financial and Quantitative Analysis, 9(1): 145-157.

Merrill, A. 1966. Behaviour of prices on Wall Street. New York: Analysis Press.

Miller, E.M. 1988. Why a weekend effect, Journal of Portfolio Management, 14: 43-48.

Pettengill, G.N. 1989. Holiday closings and security returns, Journal of Financial Research, 12(1): 57-67.

Watson, G. \& Smit, E.v.d.M. 1994. Seasonal patterns in the South African share index futures market, South African Journal of Business Management, 25(4): 155-161. 